\title{
MOTIVATION OF PROFESSIONAL CREATIVE THINKING
}

\author{
Mergalyas M. Kashapov, \\ Anna V. Leybina \\ Yaroslavl State Demidov University \\ Yaroslavl
}

The aim of this study was to reveal correlation between motivation and creative professional thinking. Four hundred and seventy-one Russians of different trades participated in the study. It was supposed that motivational structure and level of creative professional thinking were interrelated. The connection between motivational components and professional thinking was revealed. Tendencies of transition form situational level of thinking to oversituational one were determined. It was found out that motivational structure of workers with situational thinking was much more consistent than that of workers with oversituational thinking.

Key words: creative professional thinking, motivation, values, motivation structure.

Nowadays, when society is concerned with increasing work efficiency, and psychology is looking for ways to improve human resources, the problem of professional abilities study and development arises. That's why the problem of professional thinking peculiarities that are the source of professional suitability is very important. Professional suitability is a totality of personal psychic and psychophysiological features that are essential and sufficient to achieve generally accepted efficiency in a profession. It is not inherited, but rather formed by education followed by professional activity provided there is positive motivation. Factors such as system of proper material and moral stimulation, satisfaction with activity, understanding of public benefit and social results etc. lead to initiation and strengthening of professional suitability. Professional suitability forming promotes human's creative professional activity that is implemented in searching for and finding an optimal way for professional self-actualization (Petrovsky, and Yaroshevsky, 1990, p. 298). Thus, professional creativity is considered to be one of the obligatory attributes of professional development. Creativity is an activity that 
results in production of new material and spiritual values. Creativity as a cultural and historical phenomenon has personal and procedural psychological aspects. It presupposes that person has abilities, motives, knowledge, and skills that are the basis for creating new, original and unique product (Petrovsky, and Yaroshevsky, 1990, p. 393).

From this point of view, creative thinking is a type of thinking that is characterized by new product creation and new formations in cognitive activity. These new formations are related to motivation, goals, values, and meanings. Creative thinking differs from existing knowledge application process that is called reproductive thinking (Petrovsky, and Yaroshevsky, 1990, p. 226). Authors define professional thinking as a general conscious reflection of important facts, phenomena, processes in essential relations and connections that are specific for a certain type of professional activity (Kashapov, 2006). This psychological process is used to solve different, ever-changing situations, it has structure and level organization which includes motivation-goal component as one of its components. The process is presented as a continuum with following sides: dominant situational level and dominant oversituational level. Situational and oversituational levels confirm the concept of oversituational activity that is defined by V.A. Petrovsky as a subject ability to rise above the situation requirements, create goals that exceed the original problem. Due to oversituational activity, subject overcomes internal end externa scope of activity. It manifests itself in creativity, cognition, excess activity etc. (Petrovsky, 1996). Situational level is characterized by the following traits: activities are aimed at the nearest future, person can't see the logic of professional activity, quite often one's deed connection with its sequences is not apprehended, one is passive when he or she encounters a problem and surface perception of situation. This level is under the influence of accidental knowledge and personal experience, reactions are impulsive, ordinary functioning in profession scope dominates, and personal development is difficult. Oversituational level is characterized by ability to see prospects, focus not only on problem solving, but also on the causes of the problem, self-help. Main points are separated from minor points, ability to see visible as well as hidden features of situation is exhibited, and professional development is considered as a source of personal development. Creative thinking that manifests on different levels has distinctive features, and is revealed more when thinking operates on oversituational level (Kashapov, 2006; Kiselyova, 1999; Klimov, 1996).
Thus, creative professional thinking is the highest cognitive process of searching, discovery and solving a problem, revealing externally indeterminate, hidden features of professional reality (Kashapov, 2006).

T.M. Amabile supposes that not only creative abilities and experience, but also motivation is important for more effective creative activity (Amabile, 1997). Thus, a problem of professional thinking (particularly, creative professional thinking) motivation rises. Motivation is a whole set of driving forces that stimulate person's activity and have certain goal orientation (Shadrikov, 2001), it [motivation] can include person's values (Bojovitch, 1995). Specific motivation that conditions creativity is included in personality structure as well as other nonspecific motives. Basic motives and values of professionals have different intensity and can be ranked by the classical motivation and value theories (Milman, 1990; Kleinginna, and Kleinginna, 1981).

There is still no definite cause-effect relationship between motivation and thinking in psychological literature. Motivation of thinking is defined as a forecasting, strictly defined quality analysis of cognizable object and ways of its cognition orientation (Brushlinsky, 1996; Gustyakov, and Bazima, 1986), so motivation is the basis of thinking. Authors define motivation of professional creativity as a motivation that has highly inspired thinking as its basis that leads to the creation of new ways, means, and methods of performing professional tasks. As a result, it forms and improves significant social and professional personal qualities (Kashapov, 2006).

Stable certain motivational structures and relations that are correlated and regulate the general plan of human life activity are the basis of creative activity (Milman, 1990; Maslow, 1959). Importance of intrinsic motivation (Amabile, 1997; Bogoyavlenskaya, 1983; Milman, 1990; Rean, et al., 2007), motivation of achievements (Magomed-Eminov, 1987; Ponomarev, 1976; Hekhausen, 2001) is observed. Motivation types are different depending on the professional activity (Milman, 1990). This situation and necessity to create a concept of worker's creative activity motivation made us investigate motivation of professional thinking.

\section{Theoretical Hypothesis}

Motivation of professional thinking can be defined as a system of specific and nonspecific motives that are typical for some professional thinking level that influences professional performance. 
Subjects of the study are motivation of thinking, psychological and structure functional features of professional activity.

Object of the study is to establish correlations between motivation and thinking by multidimensional and structural correlation research.

\section{Tasks of the study are:}

1. Defining correlations between motivation features and professional thinking.

2. Revealing psychological structure of motivation of professional thinking by using systematic approach.

3. Conducting comparative analysis for motivation systems of professionals with situational and oversituational levels of professional thinking.

\section{Research Hypothesis:}

1. Correlation between worker's level of professional thinking and motivational structure does exist.

2. Structural and functional features of worker's motivation differ depending on the level of professional thinking.

According to theoretical hypothesis and the research tasks, particularly to construct motivational structure of professional thinking, it is reasonable to use professional thinking and general motivation, motivation of success aspiration and failure fear, intrinsic and extrinsic motivation assessment methods, for example, to construct motivational structure of professional thinking.

\section{Metod}

\section{Participants}

471 subjects participated in the research programme. They were: 189 office workers, 126 production and agricultural workers, 36 service workers, 33 workers of the commerce sector, 30 entrepreneurs, 30 freelancers, 27 scientists and teachers. 225 men, 246 women. The average age of participants was 42.4 years. 123 have university diplomas or degrees, 102 have specialized secondary education, 111 received vocational training, 108 have secondary education, 27 elementary education. 291 have children, 177 have no children. 246 are married (or cohabit), 207 are single or divorced. 51 couples took part in this research. 357 people of Russian nationality, 114 from former USSR republics or other places. All the groups (sphere of work, education, age and sex) are formed ac- cording to statistical data from the Rosstat (Federal Agency for Statistical Research of the Russian Federation) official web-site.

\section{Procedure}

In the first stage, the subjects received the professional thinking test that was done separately by each worker. This took about 15 minutes. Besides the tasks in the standard instruction, no additional stimuli or encouragements were used.

In the second stage the subjects received tests as described in the following section. Every subject got a separate desk, a chair, a pen and a set of tests. All the tests were filled one after another. The subjects were able to make a pause and leave for a short time when needed. The standard instructions were supplied in the written form with the tests.

All the subjects have filled the tests at the beginning of their working day, in the first part of week and in separate rooms. The subjects were told that they were taking part in the investigation of psychological features of people that are engaged in a certain labour activity.

\section{Instrument}

"Diagnostic of professional thinking" method is an author's (A.V. Leybina) method, that passed the proper verification procedure in the Laboratory of professional and personal development at the Yaroslavl State University in 2004-2006. The level of professional thinking (PT) of workers (situational or oversituational) was revealed by this method. This method was based on the work product analysis and is classified as constructor projective method.

The criteria of creativity and excessive activity were used as main indicators for professional thinking level assessment. The diagnostic procedure was organized in the following way: the subjects received a set of common items (three blank A4 sheets, six constructor pieces, one page of newspaper, an empty plastic one liter bottle, five old felt-tip pens) and the instruction: "There are common items in front of you. Is it possible to make something that you could use in your work out of these items? Please, give your answer in 15 minutes. You can do anything with these items to present your idea in a better way". The subjects could also use scissors, glue, a set of felt-tip pens. At the end of work the subjects were asked the following questions: "What is this?", "How could this help you in your work?", "How could you use this in your work?", "Have you a simi- 
lar object yet?", "Could you, please, describe the idea creation process and the source of this idea?", "What else could you make of these items?"

The following indicators were used for level of professional thinking assessment:

1) Indicators of creative thinking.

Indicator of originality $(\mathrm{O})$, which is determined as the relation of concrete idea originality to the general amount of ideas and it is calculated by the formula: $\mathrm{O}=\sum \mathrm{Zi} / \mathrm{X} \times 10, \mathrm{Zi}=1 / \mathrm{r}$, where $\mathrm{r}$ - is the idea frequency in the sample, $\mathrm{X}$ - total amount of ideas.

Indicator of fluency $(\mathrm{F})$, which is determined as the amount of ideas proposed in a given interval and it is calculated by the formula: $\mathrm{B}=\mathrm{X} / \mathrm{N} \min \times 10$, where $\mathrm{X}$ - general amount of ideas, $\mathrm{N}$ min - time in minutes, that was given for ideas generation and product making.

Indicator of complexity (C), which is determined as the amount of ideas created using all the given items. It is calculated by the formula: $\mathrm{C}=\mathrm{n} / \mathrm{Nit} \times 10$, where $\mathrm{n}-$ is the amount of used items, Nit - total amount of proposed items.

Indicator of flexibility $(\mathrm{Fl})$, which is determined as the variety of the ideas related to the amount of ideas. It is calculated by the formula: $\mathrm{Fl}=\mathrm{Xo} /$ Flai $\times 10$, where Flai - the amount of idea types, $\mathrm{Xo}-$ the amount of idea types, proposed by the subject. 2006).

All the coefficients are calculated by E.P. Torrance formulas (Tunik,

2) The idea efficiency.

The following types of ideas were proposed in the sample. These types were listed by the order of work efficiency decreasing, every idea type was assigned a certain amount of points (the more effective it was, the more points the idea got): 1) a device that opened new alternatives in work performing (10 points); 2) multifunctional device that combined several functions (8 points); 3 ) a device that was an unusual alternative for another already existing device (6 points); 4 ) an additional device (4 points); 5 ) devices that had mostly decorative function (2 points), 7 ) devices that had almost no connection to labour activity of the subject ( 0 points); 6 ) evices that had diversity but made labour more difficult ( 0 points).

3) The source and implementation of idea.

Points received by the answer to the question about the source of ideas: "I have never seen it anywhere, it just came to my mind" - 5 points, "I've tried to create an idea and to imagine how to implement it using the items proposed" - 5 points, "I've tried to combine items to see what I can get" - 4 points, "I have got similar ideas before" - 3 points, "I have already seen similar ideas" - 2 points, "I have tried to make usual things in an unusual way" - 1 points, "I have found the idea somewhere else" - 0 scores. For implementation subject received following points: for using proposed items (device making) -4 points, for the attempt to use proposed items (only a part of a device made) - 3 points, for two-dimensional model (draft) - 2 points, for oral description - 1 point. Comments to the device gave an additional point.

Thereby, subjects could receive from 0 to 60 points by this method that described their "Level of professional thinking" (PT) by parameters: creativity, efficiency, source and implementation of idea.

"The method of personal motivational structure assessment" (Milman, 1990). The method contains questions that were created considering labour activity (activity organization and its principles) and casual activity. Points are calculated according to the key of the method, all the points are divided between the following variables (types of motivation).

1. Life support motivation (pragmatic) (P), that reflects subject's care for life conditions, his desire to obtain material resources for himself and those he cares about.

2. Comfort and safety motivation (C). It also reflects care for means of subsistence, but in more perfect, comfortable, safe manifestation, a desire for something that gives more pleasure.

3. Motivation of status and prestige (S). It reflects both life support maintenance motivation and comfort and safety motivation in social sphere, subject's desire for the attention of other people, prestige, high status, influence and power.

4. Communication and membership motivation (M). It manifests itself in positive aspirations - affiliation, care, attention, as well as in socially negative aspirations - humiliation, courtliness, submission, aggression.

5. General activity motivation $(G)$ reflects vitality, subject's desire for energy and application of his skills in some activity.

6. Creative activity motivation (CA) reflects subjective desire to use his energy in the sphere where the creative results are possible.

7. Motivation to be generally useful (GU), is considered as the highest aspiration in humans, especially if creative results are used and achieved in the process. 
Method "Motivation of professional activity" C. Zamfir, under A.A. Rean modification (Rean, 2007). The method contains the questions that concern professional activity. By its results the following three types of motivation are defined: intrinsic, extrinsic positive and extrinsic negative.

Intrinsic motivation (IM) - is the abstract construction that describes the type of behavior determination when initiate and regulative factors arise from personality itself.

Extrinsic positive motivation (EPM) is the abstract construction that describes determination of behavior in situations when factors that initiate and regulate activity are outside a person and are a kind of encouragement.

Extrinsic negative motivation (ENM) is the abstract construction that describes determination of behavior in situations when factors that initiate and regulate activity are outside the person and are a kind of punishment.

"Method of success aspiration and fear of failure assessment" (Rean, 2007). After the points interpretation the level of success aspiration or the level of failure fear is revealed (SAFF). It shows how much the subject that begins his activity tries to achieve constructive and positive result (more points), or tries to avoid punishment, failure, blame (fewer points).

\section{Measures registration}

The results of diagnostic of professional thinking method were registered by the experimenter. Answers for other tests were registered by subjects themselves in special printed forms that were supplied wi th the method. Name and family name were pointed in every print form. Age, work experience, education, marital status, and children - were mentioned in the first printed form. All the data were processed according to the tests' keys.

\section{Statistical criteria}

The following statistic methods: correlation analysis (r-criterion), for correlation between motivational components and professional thinking; structural analysis, factorial analysis for data reduction (principal components), varimax rotation were used. All the data, received by tests were processed by "STATISTICA 5.5" program.

\section{Results}

The following results were received after processing

Table 1

Descriptive statistic of investigation results

\begin{tabular}{ccccc}
\hline Variables & Mean & Max & Min & SD \\
\hline PT & 27.61 & 56 & 4 & 7.32 \\
P & 20.03 & 44 & 10 & 6.11 \\
C & 20.41 & 47 & 12 & 6.23 \\
S & 21.22 & 46 & 5 & 8.48 \\
M & 22.4 & 45 & 15 & 6.51 \\
G & 20.17 & 42 & 11 & 6.24 \\
CA & 25.13 & 41 & 10 & 7.11 \\
GU & 22.44 & 45 & 6 & 6.34 \\
IM & 3.18 & 5 & 0.5 & 1.7 \\
EPM & 2.41 & 5 & 0.5 & 1.12 \\
ENM & 2.3 & 5 & 1 & 1.42 \\
SAFF & 11.17 & 20 & 1 & 6.01 \\
\hline
\end{tabular}

Correlation analysis results

By examining the correlation analysis results for the methodic of PT assessment and personal motivation assessment the straight correlations were revealed between PT level and motivation of creative activity, and between PT level and motivation to be generally useful. The invert correlations were revealed between level of PT and motivation of comfort and safety, PT level and communication and membership motivation, PT level and life support maintenance motivation (table 2). All the samples were divided into two groups by the criteria "points by comfort and safety motivation scale" (C). The average value was 21 points, thus, there were workers who had got more than 20 points by this type of motivation in one group, and those who has got 20 points and less. The level of PT between these groups was compared. By this correlation of PT level with comfort and safety motivation in the group $(C>20) r=-0.46$ $(\mathrm{p}<0,01)$. Correlation in another group $(\mathrm{C}<21)$ is not significant.

Straight correlation between PT level and intrinsic motivation and PT level and invert correlation between PT level and extrinsic negative motivation (table 3 ). 
Correlation coefficients for V.E. Milman's method of personal motivation structure and method of PT level assessment

\begin{tabular}{cc}
\hline Motivation & Professional thinking assessment \\
\hline G & $-0,13$ \\
CA & $0,61^{\star}$ \\
C & $-0,37^{\star}$ \\
GU & $0,27^{\star *}$ \\
P & $-0,30^{\star *}$ \\
S & $-0,28^{\star *}$ \\
\hline
\end{tabular}

* - significance level p $<0,05$; ${ }^{*}$ - significance level $\mathrm{p}<0,01 ; \mathrm{G}$ - General activity motivation; CA - motivation of creative activity; $\mathrm{C}$ - comfort and safety motivation; GU - motivation to be generally useful; $\mathrm{M}$ - motivation of communication and membership; P - life support motivation; S - motivation of status and prestige.

Correlation coefficients for C. Zamfir's method

Table 3 and method of PT level assessment

\begin{tabular}{lc}
\hline Motivation & Professional thinking assessment \\
\hline Intrinsic & $0,47^{\star}$ \\
Extrinsic positive & $-0,17$ \\
Extrinsic negative & $-0,32^{\star}$ \\
\hline
\end{tabular}

* - significance level $\mathrm{p}<0,05 ;{ }^{* *}$ - significance level $\mathrm{p}<0,01$.

\section{Factor analysis}

Table 4

Matrix of factor analysis

\begin{tabular}{cccccc}
\hline № & Eigenvalue & $\begin{array}{c}\text { \% total } \\
\text { variance }\end{array}$ & $\begin{array}{c}\text { Cumulative } \\
\text { eigenvalue }\end{array}$ & $\begin{array}{c}\text { Cumulative } \\
\%\end{array}$ & $\begin{array}{c}\text { Explored } \\
\text { variance }\end{array}$ \\
\hline Factor 1 & 6,425187 & 34,22893 & 7,541289 & 36,52174 & 5,07492 \\
Factor 2 & 2,168361 & 12,34905 & 10,42175 & 50,7250 & 3,68017 \\
Factor 3 & 1,343566 & 5,948261 & 13,22803 & 64,92281 & 1,13420 \\
\hline
\end{tabular}

Dimension of matrix: 11 variables (columns), 471 subjects (rows). Three factors were revealed (weight of factor $>0,7$ ) (table 4).

Based on factor analysis the following three factors were revealed:

1. Motivation of creative activity, motivation to be generally useful, intrinsic motivation, motivation of success aspiration and failure fear.

2. General activity motivation, motivation of communication and membership, life support maintenance motivation, motivation of status and prestige.

3. Extrinsic positive motivation.

\section{Structural correlation research}

By the results of PT level assessment method, subjects were divided into two groups with dominant situational (41 subjects) and dominant oversituational professional (37 subjects) thinking.

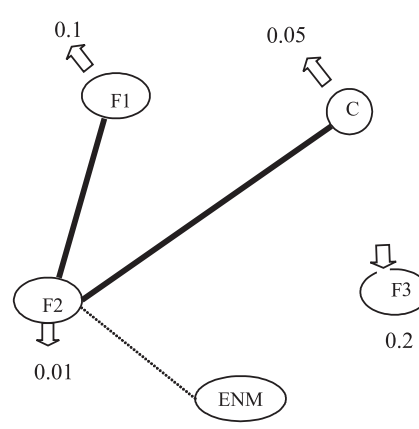

Oversituational level of professional thinking

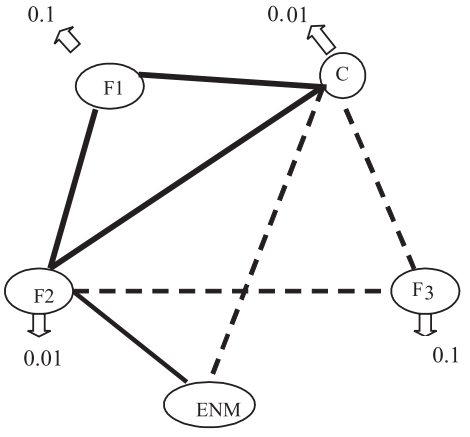

Situational level ofprofessional thinking
Note: — - strait correlation with significance level 0,01; - - - strait correlation with significance level 0,$05 ; \ldots$ invert correlation with significance level 0,$01 ; \square$ - significance level for correlation with PT level assessment method; F1 - factor 1; F2 - factor 2; F3 - factor 3; C - motivation of comfort and safety; ENM - extrinsic negative motivation.

Figure 1. Structurogram of motivational components for workers with situational and oversituational levels of professional thinking 
System coherence index for workers with oversituational level of professional thinking (Figure 1) $\mathrm{SCI}=6$, system divergence index $\mathrm{SDI}=2$, system organization index $\mathrm{SOI}=4$. The heaviest component is Factor 2 motivation of general activity that tends to maintain lifestyle (weight coefficient $(\mathrm{wc}=6)$. Correlation coefficients with PT level assessment method: Factor $2-(r=0,801(p<0,01))$, Factor $1-(r=0,44(p<0,01))$ motivation of comfort and safety $-(\mathrm{r}=0,3759(\mathrm{p}<0,05))$, Factor 3 $(\mathrm{r}=-0,2472(\mathrm{p}<0,2))$.

System coherence index for workers with situational level of professional thinking (Figure 1 ) SCI = 11, system divergence index SDI = 3, system organization index SOI $=8$. The heaviest components are: Factor 2 $(\mathrm{wc}=7)$, motivation of comfort and safety $(\mathrm{wc}=6)$; Factor $1(\mathrm{wc}=4)$. Correlation coefficients with PT level assessment method: Factor 1 $(\mathrm{r}=-0,3075(\mathrm{p}<0,1))$, Factor $2-(\mathrm{r}=-0,659(\mathrm{p}<0,01))$, motivation of comfort and safety $-(\mathrm{r}=-0,6565(\mathrm{p}<0,01))$, Factor $3-(\mathrm{r}=-0,2014$ $(\mathrm{p}<0,1))$.

System coherence index of subject's with situational thinking level $(\mathrm{SCI}=8)$ is greater than that of subject's with oversituational thinking level (SCI $=4)$. Coefficient of correlation between these motivation systems is $\mathrm{r}=0,19(\mathrm{p}<0,2)$.

\section{Discussion of results}

\section{Connections between motivational}

\section{characteristics and professional thinking}

Statistical analysis provided results, which both correspond to existing psychological theories as well as results that contradict them.

Creative activity motivation has a strong positive correlation with creative thinking level. This fact corresponds well with the theory, which describes creative activity motivation as specific to oversituational activities and professional efficiency increase. Constant strive for creative self-actualization within one's profession can lead to rather successful results.

Comfort and safety motivation has a rather significant negative correlation with level of professional thinking, which also corresponds with theory (Ponomarev, 1976). Although it was found, that if strive for comfort didn't exceed average values, it couldn't be stated that such a tendency interferes with high efficiency of professional thinking. The big- ger role this motive plays in professional activity regulation, the higher negative correlation level is.

Communication and membership motivation has a negative correlation with professional thinking level which contradicts several theories (Tikhomirov, 1975). Probably, when communication is the leading motif, an employee concentrates more on socializing with his colleagues, while missing out some important moments of professional activity, which decreases his desire for professional efficiency. We still monitored this correlation during the PM diagnostics, regardless of the fact that participants, who had been tested, were unable to communicate with anyone. It's probably because of the image of professional efficiency and efforts necessary to achieve results that these people develop during their professional personality establishment. On the other hand, the fact that they were diagnosed individually could have affected productivity of people, who value communication. In group tests they, perhaps, could have shown better results.

Life support motivation (pragmatic motivation) has a high negative correlation with a level of creative professional thinking. This can be explained in the following way: worrying too much about material resources can suppress one's creative activity (Klimov, 1996), and it is often enough for an employee to perform only necessary and mundane actions or actions suggested by one's supervisors.

Intrinsic motivation has a positive correlation with professional thinking level. This corresponds well with theoretical data (Amabile, 1997; Bogoyavlenskaya, 1983; Millman, 1990; Rean, et al, 2007). Employees, who are interested in the professional activity itself, have a high level of professional thinking development. Professional activity is interesting to such people, it becomes a source of inspiration, self-esteem, development and interesting professional problems for them. This, without doubt, provides maximum professional efficiency and professional thinking development, while extrinsic negative motivation has a high negative correlation with professional thinking level, which also corresponds to theory (Rean, et al., 2007). Many employees don't need extraordinary activity and several mental resources activation to succeed at their job. That's why employees who have only extrinsic negative motivation use only situational thinking aimed at immediate mistakes correction. Following straight and direct instructions is even better for them, for it doesn't provoke any negative consequences. 


\section{Psychological structure}

of professional thinking motivation

In the psychological motivation structure there're distinct factors described above such as comfort and safety motivation, extrinsic negative motivation, as well as some other factors:

The first factor includes creative activity motivation, desire to be useful to the society, intrinsic motivation, achievement motivation, fear of failures. This factor includes peculiarities often encountered in creative people (Bogoyavlenskaya, 1983; Brushlinsky, 1996; Ponomarev, 1976; Gippenreiter, and Falikman, 2006). Thus, this factor was named "Creation factor".

The second factor includes general activity motivation, communication motivation, life support motivation, status and prestige motivation. These parameters reflect a person's strive for an active life position, acquiring material resources and social recognition, which are the sign of prosperity in modern Russian society. Thus, this factor was named "Prosperity factor".

The third factor: extrinsic positive motivation was grouped into a separate factor. This is probably because all desires which originate from outside an employee's personality, including those which aren't connected with his motifs, but somehow affect them, were included into this factor and affect his or her motivation system and professional activity. Thus, this factor was named "Outer stimulation factor".

\section{Comparative analysis of motivations of workers}

\section{with situational and oversituational thinking}

There are similar and different basic motivational components in motivational structures of workers with situational and oversituational professional thinking. Prosperity factor is a similar basic component. Among special basic motivation components there are special basic components distinguished in motivation structure of employees with situational thinking. These are: motivation of comfort and safety as well as creation factor.

System organization index for workers with situational thinking $(\mathrm{SOI}=8)$ exceeds that of workers with oversituational thinking $(\mathrm{SOI}=4)$. This gives us the right to suppose that workers with situational professional thinking level have better adaptation abilities than workers with oversituational thinking and that it is achieved by minimization of efforts in result achieving process (Karpov, and Lenkov, 2006). Labour that presupposes large amounts of efforts (including creative efforts) and the desire to achieve highest results in any activity requires robustness (Klimov, 1996). Thus, workers with situational level of professional thinking are inclined to use common approaches, methods, recommendations and colleagues' experience instead of creative approaches to achieve professional competence and to save psychological resources. According to this, it can be stated that workers with oversituational level of professional thinking have more psychological resources or are in need of psychological support (self regulation skills, recovery of one's forces, etc.).

The tendency-level correlation between motivation system's weight coefficients shows that these motivation systems of both situational and oversituational thinking are heterogeneous. It can be concluded that abstract motivation system model that was proposed by authors, transforms its features significantly while functioning on different thinking levels. This may prove our hypotheses that there is a correlation between motivational system and level of professional thinking. Obviously, authors can't claim that all workers have identical motivational structure and that this model can be entirely applicable to any person, because influence of other factors was not taken in consideration in this study. Regarding proposed motivation model, however, it is possible to find out and plan a way to improve professional thinking and explain some reasons of professional effectiveness decrease. In addition, the revealed tendency correlation between motivational systems opens the gate for influencing motivation in order to improve professional activity.

\section{Interpretation of motivation systems}

comparative analysis data

It is possible to interpret correlations inside motivation system. Prosperity factor is obviously correlated with creative factor in the motivation system of workers with oversituational level of professional thinking, because it provides comfort to them. As it was mentioned above, oversituational activity manifestation both give pleasure and lead to discomfort. Perhaps, that's why there is no significant correlation between these two components. At the same time, prosperity factor has inverse correlation with extrinsic negative motivation. It is probably connected with the fact that people with developed oversituational thinking are able to see the consequences of their own deeds and are inclined to avoid 
punishment to save their prosperity. Outer stimulation factor has no significant correlations in this motivation structure, but is included in the structure and has a positive connection with professional thinking. This may show that positive stimuli are important themselves for workers with such level of thinking and are independent stimuli for oversituational activity. It is possible that there is some connection between this factor and other components of the motivation system through the use of other psychological agents (values, attitudes, etc.), however, these agents weren't detected in this study.

Prosperity factor is also a basic factor in the motivation system of workers with situational level of professional thinking. And so, motivation of comfort and safety is also defined as the basic one. Desire for comfort alone may lead workers to saving their efforts. Comfort and safety can be connected with reward achievement (positive stimulation) and with attempts to save work efforts or to work only out of fear of punishment The important moment is that creation factor of this motivation system is also the basic one. It has positive correlation with motivation of comfort and safety and prosperity factor. This may show that workers with situational level of professional thinking are able to get satisfaction and benefits from creation that can give prosperity (respect, money, bonuses, privileges, etc.) and the feeling of comfort and safety from understanding that everything is going on in a proper way. And the creation can be essential and sufficient and be connected with oversituational activity.

\section{Conclusions}

Results of the study confirm theoretical hypothesis and lead to the following conclusions:

1. Motivational system of workers with situational and oversituational levels of professional motivation are heterogeneous. Five components were revealed in the motivational structure, they were: creation factor, prosperity factor, outer stimulation factor, motivation of comfort and safety, and extrinsic negative motivation.

2. Motivational structures differ according to the level of professional thinking. Motivational structure of workers with situationa level of professional thinking is more consistent, and so they have better adaptive abilities.
3. Correlations between motivational components and professional thinking were revealed. It indicated that motivation and professional thinking had similar tendencies while transcending from situational to oversituational thinking level. During this process, influence of motivation of comfort and safety, motivation of communication and membership, motivation of life support, extrinsic negative comes down, and influence of creative motivation, motivation to be generally useful, intrinsic motivation rises.

\section{References}

Amabile, T.M. (1997). Motivating creativity in organizations: On doing what you love and loving what you do. California Management Review, 40. P. 39-58.

Barron, F. (1968). Creativity and personal freedom. N.Y.: Van Nostrand.

Bogoyavlenskaya, D.B. (1983). Intellektual'naya aktivnost' kak problema tvorchestva [Intellectual activity as a problem of creativity]. Rostov.: Izdatelstvo Rostovskogo universiteta.

Bozhovitch, L.I. (1995). Izbranny'e psikhologicheskie trudy'. Problemy' formirovaniya lichnosti [Selected psychological works. Problems of personality forming]. Moskva: Izdatel'stvo Mezhdunarodnaya pedagogicheskaya akademiya.

Brushlinsky, A.V. (1996). Subekt: myshlenie, uchenie, voobrazhenie [The subject: thinking, learning, imagination]. Moskva-Voronezh.

Gippenreiter, U.B., and Falikman, M.V. (eds.) (2006). Psihologiya motivatsii $i$ emotsiy [Psychology of motivation and emotions]. Moskva: CheRo.

Gustyakov, N.A., Bazima, B.A. (1986). K voprosu o motivatcii myshleniya [On motivation of thinking]. Vestnik KHGU. P. 13-17.

Hechausen, H. (2001). Psihologiya motivatsii dostizheniya [The psychology of achievement motivation]. Sankt-Peterburg: Piter.

Karpov, A.V., and Len'kov, S.L. (2006). Strukturno-funktsional'noe stroenie deyatel'nosti informatsionnogo haraktera [Structural-functional composition of informational activity]. Tver': Tverskoy gosudarstvennyj universitet.

Kashapov, M.M. (2006). Psihologiya tvorcheskogo myshleniya professionala [Psychology or professional creative thinking]. Moskva: PER SE.

Kiselyova, T.G. (1999). Sotsial'no-psihologicheskie osobennosti urovnevyh harakteristik professional'nogo pedagogicheskogo myshleniya $v$ protsesse otsenivaniya [Sociopsychological features of professional pedagogical thinking level characteristics in the estimation process]. Yaroslavl. 
Kleinginna, P., and Kleinginna, A. (1981). A categorized list of motivation definitions, with suggestions for a consensual definition. Motivation and Emotion, 5. P. 263-291.

Klimov, E.A. (1996). Psihologiya professionala [Psychology of a professional]. Moskva: Izdatel'stvo «Institut prakticheskoy psihologii»; Voronezh: SPU “MODEK”.

Kornilov, U.K. (1984). Myshlenie v proizvodstvennoy deyatel'nosti [Thinking in production activity]. Yaroslavl: YarGU.

Magomed-Eminov, M.Sh. (1987). Motivatsiya dostizheniya: struktura i mehanizmy [Motivation of achievements: the structure and mechanisms]. Moskva.

Maslow, A. (1959). Creativity in self-actualising people. In H.H. Anderson (ed.) Creativity and its cultivation. Harper.

Milman, V.E. (1990). Metod izucheniya motivatsionnoy sfery lichnosti [The method of personal motivation structure investigation]. In Praktikum po psihodiagnostike. Psihodiagnostika motivatsii i samoregulyatsii. Moskva.

Petrovsky, V.A. (1996). Lichnost'v psihologii. Paradigma subektnosti [Personality in psychology. Paradigm of subject]. Rostov-na-Donu.

Petrovsky, A.V., and Yaroshevsky, M.G., (eds.) (1990). Psihologiya (slovar') [Psychology (dictionary)]. Moskva: Politizdat.

Ponomarev, J.A. (1976). Psihologiya tvorchestva [Psychology of creativity]. Moskva: Nauka.

Rean, A.A., Bordovskaya, N.V., and Rozum, S.I. (2007). Psihologiya i pedagogika: Uchebnik dlya vuzov [Psychology and pedagogics. Textbook for colleges]. Sankt-Peterburg: Piter.

Shadrikov, V.D. (2001). Vvedenie v psihologiyu: motivatsiya povedeniya [Introduction to psychology: motivation of behavior]. Moskva: Logos.

Teplov, B.M. (1985). Izbrannye trudy: $v 2$ tomakh [Selected works in two volumes]. Moskva: Pedagogica.

Tikhomirov, O.K. (ed.) (1975). Psychological research of creative activity [Psychological research of creative activity]. Moskva: Nauka.

Tunik, E.E. (2006). Diagnostika kreativnosti. Test E. Torrensa. Adaptirovanny'j variant [Creativity assessment. Test by E.Torrancet. Adapted version]. Sankt-Peterburg: Rech. 